\title{
Challenges of the environmental management of Mining in Mexico
}

\author{
Retos de la Gestión Ambiental de la Minería en México
}

\author{
RIVERA-ACOSTA, Patricia †* \& MARTINEZ-TORRES, Rosa Elia \\ Tecnológico Nacional de México, Instituto Tecnológico de San Luis Potosí
}

ID $1^{\text {st }}$ Author: Patricia, Rivera-Acosta / ORC ID: 0000-0002-8254-0005, Researcher ID Thomson: X-2388-2019, CVU CONACYT ID: 232611

ID $1^{\text {st }}$ Coauthor: Rosa Elia, Martinez-Torres / ORC ID: 0000-0001-8936-9207, Researcher ID Thomson: X-3124-2018, CVU CONACYT ID: 953355

DOI: $10.35429 / J A F .2019 .19 .6 .26 .35$

Recibido June 20, 2019; December 30, 2019

\begin{abstract}
Mexico has a high potential in terms of mineral resources, promoting investment, employment generation and strong fiscal contributions; mining activity at the national level has incorporated strategies that also allow it to comply with environmental protection requirements, so it recognizes that sustainable development allows it to harmonize this economic growth, with the right of future generations to achieve their well-being. Based on the descriptions provided in a Focus Group composed of the members of Minera Tierra Adentro, environmental challenges are identified that the Mexican Mining and Metallurgical Industry faces with respect to the fulfillment of goals derived from the Sustainable Development Goals (UN, 2015). Therefore, the objective of this work is to describe the main environmental challenges currently faced by mining companies in Mexico, to contribute as a sector oriented towards sustainability. The methodology, of qualitative nature, includes documentary research and the analysis of different sources of information through its reading and reflection, the Focal Group is also used as a technique for the collection of information.
\end{abstract}

Sustainable development, Mining and Metallurgical Industry, Remediation, Environmental challenges.

\begin{abstract}
Resumen
México tiene un alto potencial en cuanto a recursos minerales, promoviendo inversión, generación de empleo y fuertes contribuciones fiscales; la actividad minera a nivel nacional ha incorporado estrategias que además, le permiten cumplir con requerimientos de protección al ambiente, por lo que reconoce que el desarrollo sustentable le permite armonizar este crecimiento económico, con el derecho de las generaciones futuras para alcanzar su bienestar. A partir de las descripciones que se proporcionan en un Grupo Focal integrado por los miembros de Minera Tierra Adentro, se identifican retos ambientales que la Industria Minero-metalúrgica Mexicana afronta con respecto del cumplimiento de metas que se derivan de los Objetivos de Desarrollo Sostenible (ONU, 2015). Por lo cual, el objetivo de este trabajo es, describir los principales retos ambientales que en la actualidad deben contrarrestar las empresas mineras de México, para contribuir como un sector orientado a la sustentabilidad. La metodología, de corte cualitativo, comprende la investigación documental y el análisis de distintas fuentes de información a través de su lectura y reflexión, se utiliza además, el Grupo Focal como técnica para la recolección de la información.
\end{abstract}

Desarrollo sostenible, Industria Minerometalúrgica, Remedición, Retos ambientales

Citation: RIVERA-ACOSTA, Patricia \& MARTINEZ-TORRES, Rosa Elia. Challenges of the environmental management of Mining in Mexico. Journal of Administration and Finance. 2019, 6-19: 26-35

*Correspondence to Author (email: erika.acosta@itson.edu.mx)

$\dagger$ Researcher contributing first author. 


\section{Introduction}

The Mining and Metallurgical Industry is considered an economic factor in the world, so its importance cannot be ignored, which leads nations to study more friendly and sustainable processes, since by nature, their extraction usually impacts the environment . Mexico has a high potential in terms of mineral resources and the sector continues to give positive results in investment, job creation and strong fiscal contributions. Beyond its economic participation, the social scope of mining extends to 24 states of Mexico with a direct or indirect incidence in 83 million Mexicans, in short the incursion and development of this activity is a lever for economic development and society (CAMIMEX, 2006 and 2019).

Sustainability has become an essential asset and a trend for companies in any sector, although nowhere else than in mining, that is why understanding this commitment is emerging as an essential part of a business strategy; In the same way, companies are increasingly aware of environmental impacts, hence mining is one of the most important sources of pollution to the environment.

Mining in Mexico carries out its operations within the concept of sustainable development and respects environmental legislation through the application of additional tools such as: ISO standards, environmental auditing, socially responsible company, environmental certifications, etc. (CAMIMEX, 2006)

\section{Theoretical foundation}

\section{Definitions and dimensions of Sustainability}

In 1992 at the United Nations Conference on Environment and Development (UNCED), also called the "Earth Summit", the fact that environmental protection and natural resource management must be integrated into the socioeconomic issues of poverty and underdevelopment. The Brundtland Commission (1987) demonstrated that social, environmental and economic needs must balance each other in order to obtain long-term sustainable results.
In this report, the concept of sustainable development is disseminated as "one that responds to the needs of the present equally, but without compromising the chances of survival and prosperity of future generations". It also states that poverty, equality and environmental degradation cannot be analyzed in isolation, placing poverty as one of the causes and consequences of environmental problems.

This concept assumes that the economic, social and environmental objectives of development must be defined in terms of sustainability with their dimensions: economic, social and environmental (figure 1):

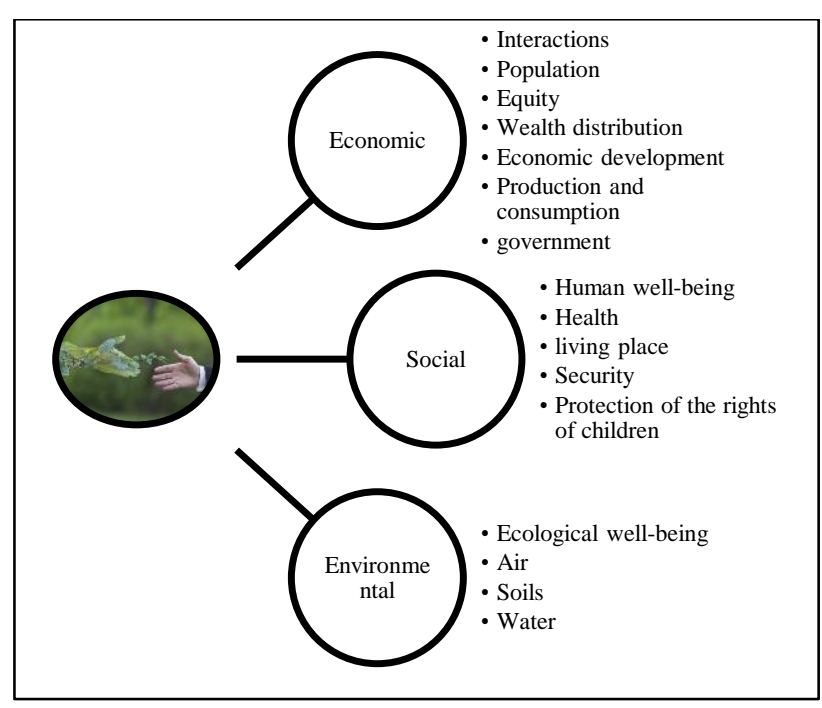

Figure 1 Sustainability Dimensions Source: Own elaboration based on CMMAD (1987)

\section{Background and Principles of Sustainability}

Sustainable development is defined in the report Our Common Future, published by the World Commission on Environment and Development in 1987 as "one that meets current needs without compromising the ability of future generations to meet their own needs" ( cited by Gómez, 2012, p.61).

However, this definition of almost 30 years ago has become obsolete, because that long-awaited future has become our present, where the effects of climate change are already being lived and the amount of resources that the new generations will have are uncertain, natural resources they are running out and being consumed at a faster rate than the earth is capable of regenerating them (Belda, 2018). 
According to Hernández (2009), economic development has been responsible for this situation, privileging an industrial model that pursues high growth rates causing the deterioration of nature, which has its origins for more than 200 years with the Revolution Industrial.

In 1983-1984, the UN and UNEP created the World Commission on Environment and Development, the Brundtland Report called Our Common Future (1987), which specifically talks about sustainable development, is prepared. In the UN Millennium Development Goals (2000), objective seven was to ensure environmental sustainability.

\section{Sustainable Development Goals}

Likewise, at the United Nations Organization (UN) in September 2015, the 2030 Agenda for Sustainable Development was approved at a historic summit held in New York City, which stands out as a momentous agenda as it states that " it will serve as an action plan for the international community and national governments to promote prosperity and common welfare in the next 15 years".

This agenda sets out 17 sustainable development objectives (SDGs), with 169 goals of an integrated and indivisible nature that contemplate the dimensions: economic, social and environmental, of those objectives are mentioned those related to the environmental dimension and which in this document are consecutively numbered:

$\begin{array}{ll}\text { 1. } & \text { Clean water and sanitation } \\ \text { 2. } & \text { Affordable and clean energy } \\ \text { 3. } & \text { Innovation and infrastructure industry } \\ \text { 4. } & \text { Sustainable cities and communities } \\ \text { 5. } & \text { Responsible production and } \\ \text { 6. } & \text { Wensumption } \\ \text { 7. } & \text { Life of terrestrial ecosystems }\end{array}$

Each objective has goals that must be achieved by 2030 , hence various initiatives of international organizations have been presented in order to unify the process of implementation, development, communication and evaluation of these practices offered different tolos

\section{Global Reporting Initiative}

One of the most important initiatives is the one carried out by the Global Reporting Initiative (GRI) which aims to be used by companies to prepare sustainability reports that include three dimensions: economic, environmental and social. It refers to the universal principles of the Global Compact, related to the environmental management of companies: a) they will maintain a preventive approach that favors the environment, b) they will promote initiatives that promote greater environmental responsibility and, c) they will favor the development and the diffusion of environmentally friendly technologies.

\section{International Council on Mining \& Metals (ICMM)}

Promotes among its members, practices focused on sustainable development and responsible production of minerals and metals. The associated companies must apply the ten principles of sustainable development of the ICMM:

1. Apply ethical business practices, sound corporate governance systems and transparency to support sustainable development.

2. Integrate sustainable development in the strategy and decision-making processes in companies.

3. Respect the human rights, cultures, customs and values of employees and communities affected by our activities.

4. Implement strategies and effective risk management based on scientific knowledge.

5. Apply continuous improvement in our health and safety performance with the aim of zero damage.

6. Seek continuous improvement in our environmental performance (water, energy management and use, climate change).

7. Contribute to the conservation of biodiversity and the protection of soils and water resources.

8. Facilitate and support the design, use, reuse, recycling and responsible disposal of our products (metals and minerals).

9. Contribute to the economic, social and institutional development of the communities and countries where our operations are located. 
10. Commit proactively with the main stakeholders on sustainable development challenges and opportunities. Prepare annual report of environmental, economic and social performance using the GRI.

In this context we can see that there is a direct connection between the scope of the Global Compact, the Sustainable Development Goals, the GRI indicators and in a similar way, with the ten principles of sustainable development of the ICMM.

\section{Sustainable Development and Environmental Management}

The Report of the United Nations Environment Program (UNEP, 2010) promotes the greening of economies to achieve sustainable development; The green economy initiative offers solutions that improve human well-being, reduce inequalities and help rebuild the economy on a sustainable basis. Its objective is to help countries that request it to achieve ecological economies as a way towards sustainable development. Conceptually, sustainable development is linked to environmental management, which promotes the rational use of natural resources and the protection of the environment.

Finally, we must add that the environmental dimension of sustainability refers to the impacts of an organization on living and inert natural systems, including ecosystems, soil, air and water. It is divided into nine goals aimed, among other things, at halting and reversing land degradation, curbing the loss of biological diversity, recovering degraded forests and increasing reforestation and ecosystem restoration.

In turn, the environmental indicators cover performance in relation to the inflows (materials, energy, water) and outflows (discharged emissions, waste).
They also include performance in relation to biodiversity, legal environmental compliance and other relevant data such as expenses of an environmental nature or the impacts of products and services, adding the following environmental aspects: materials, energy, water, biodiversity, emissions, discharges, waste, products and services, regulatory compliance, transportation and finally general aspects (UN, 2011).

\section{Aspects to consider in the Mining and}

\section{Metallurgical Industry.}

\section{A. Mining environmental liabilities}

One of the most worrying situations related to mining is the Mining Environmental Liabilities (PAM), in much of the world. It refers to the "environmental impacts generated by abandoned mining operations with or without an identifiable owner or operator and, where no closure of mines regulated and certified by the corresponding authority has been made" (Oblaser and Chaparro, 2008).

The United States Environmental Protection Agency (EPA) ${ }^{l}$ defined as abandoned mining sites, those lands, waters and basins contaminated or damaged by the extraction, benefit or processing of ores ${ }^{2}$ and minerals The term abandoned mining site includes those areas where mining activity is temporarily inactive.

In the context of the Economic Commission for Latin America and the Caribbean (ECLAC) it is described that MAPs present or may present a safety or contamination risk for both human health and the environment (Oblaser and Chaparro, 2008: 12 ; Saade, 2014). In the case of Mexico, the Ministry of Environment and Natural Resources (SEMARNAP) defines PAMs as: "those sites contaminated by the release of hazardous materials or wastes that were not promptly remedied to prevent the dispersion of pollutants, but which imply an obligation of remediation ".

\footnotetext{
${ }^{1}$ Enviromental Proteccion Agency

${ }^{2}$ https://es.thefreedictionary.com/menas . Parte del filón que contiene minerales útiles que requieren un proceso de elaboración para poder ser utilizados en la industria. E.g. bauxita, mena de aluminio 


\section{B. Remediation}

Consequently, the mining activity, the removal of soils, the extraction of rocks and minerals, the deposit of waste, the construction of mining facilities can have a strong impact on ecosystems, on land and aquatic life during the operation. mining and also after the abandonment of it.

The environmental impact can be defined as modifications that the human being causes, generating ecological imbalance (SEMARNAT, 2013), the evaluation of these impacts, supposes conditions to which the activities that trigger unbalance must be subjected.

These impacts, within their evaluation, require a thorough review of methods in their processes. In the Mining Industry, this review and implementation of activities that counteract or minimize environmental impacts is known as remediation (Martínez and Rivera, 2017).

Remediation is a set of activities that are articulated to modify the state of alteration caused. Other concepts are linked: restoration, rehabilitation, all aimed at promoting the restoration of ecological processes (Arranz and Alberruche 2008).

\section{Methodological Foundation}

Minera Tierra Adentro (MTA), a small administrative, technical and operational consulting firm for the Mining and Metallurgical Industry, intervenes in a particular way with companies in the sector providing, through its members, experience in technical, operational, administrative and legal solutions, participating reliably with the safety and environmental aspects; installed in the capital city of San Luis Potosí, Mexico, it is made up of a selected team of highly qualified multidisciplinary earth science professionals.

As part of a collaborative work, subject to a line of environmental management research, the authors, participating in the generation of scientific knowledge of the MTA team, set the standard for the realization of a Focal Group that promotes the dissemination of information as agents of change within the miningmetallurgical sector.

\section{Contextualization}

The environmental damage that the Mining and Metallurgical Industry can cause, is reflected in deterioration of natural resources and ecosystems, which in addition, is not considered as the environmental cost of production, so its remediation is not formally described, prevailing as debt with the society (Melo, 2011).

As part of the awareness that MTA promotes with its clients and in favor of knowledge generation, an investigation is structured about the challenges that are required to strengthen the environmental strategies of companies in the mining-metallurgical sector. These challenges must be aligned with the global efforts that organizations have developed to recover the natural environment.

\section{Justification}

Mining activity produces prosperity and economic development, but the environmental impact on terrestrial ecosystems cannot be avoided. In light of the current challenges of mining, it is important for the sector to improve its approach to sustainability in its three dimensions: environmental, economic and social.

\section{Problem statement}

Industrial mining processes cause adverse effects on soil, air and water in the ecosystems where the companies in the sector are located. The sustainability agenda in mining is expanding, the industry has a lot to lose if it does not understand and manage the global trend, such as increasing pressure on natural resources, progressive demands for transparency and global action on climate change which affects all intensive companies.

\section{Overall objective}

Describe the main environmental challenges currently faced by Mexican mining companies, to contribute as a sustainability-oriented sector. 


\section{Methodology}

To achieve the objective, the use of a constructive-interpretative methodology is proposed, based on qualitative epistemologies that imply highlighting knowledge as human production generated from realities related to knowledge, building on experiences, in this case of personnel involved with mining and environmental aspects, to achieve articulations between theoretical foundations and real aspects through scientific research, to achieve understandable descriptions of the events studied (Hamui and Varela, 2013). The method used for this is the Focus Group.

\section{Focus group}

To facilitate the discussion and promote a practical and effective theoretical foundation to be disseminated in the mining-metallurgical sector, the knowledge and experience of people involved in it is explored. To do this, a focus group is being developed and conducted (Hamui and Varela, 2013) where in an opinion space, aimed at capturing explanations of observable and quantitative data captured from the environment, through previously prepared questions, collective information is obtained that It involves a variety of attitudes, solutions, experiences and beliefs of the participants so that through qualitative interpretations, constructivist descriptions of the knowledge of relevant environmental aspects that the Mining and Metallurgical Industry lives today are obtained, and which in this document are called Challenges

The focus group is made up of the researchers, who direct the activity and, based on the experience of the rest of the participants, describe the results; the Director of MTA mining engineer with more than 50 years of experience in the field, founder and main partner of the firm, a mining engineer expert in safety and environment with 45 years of experience, an industrial engineer, specialist in planning of mining work with 10 years of experience in this industry; a civil engineer, with more than 35 years of experience in mechanical metal construction, management and sales, collaborating as a representative of MTA with foreign sustainable cutting equipment, for the mining industry.

\section{Information Collection Instrument}

Based on the theoretical foundations about sustainability and Sustainable Development Goals, questions arise that support this research and are presented in the Focus Group. The description that the members backed by their experience and knowledge provide to each questioning, gives the structure of the challenges that the mining industry faces as the organisms have indicated as viable paths to recover the environment.

In this way, questions are raised regarding the current actions that impact the environment and that align with the sustainability foundations described in the 2030 Agenda (UN, 2013), from which they have been extracted and re-numbered to fulfill the purpose of this document, those related to environmental damage.

These questions are presented in plenary so that the members respond according to their own experiences and different experiences in the field; Some of these are presented below for the purpose of preparing this document, being the most representative and generally involving the selected SDGs:

1. With respect to guaranteeing free water (SDG 1) of impurities and accessible to all, considering mining-metallurgical processes that cause shortages and poor quality, in addition to the risk of impact to groundwater, how does the mining industry promote remedy or rehabilitate wells, clean, prevent droughts?

2. Does the mining industry have financial support that promotes investments in infrastructure (SDG 3, 4, 5) both from the same company (starting and withdrawing) and to empower communities by achieving increased productivity in income, improvements in health aspects, of health, education, urbanization, that allow to be more resistant to climatic and sustainable changes? 
3. Do the processes of the Mining and Metallurgical Industry (SDG 5), consider alternatives for the channeling of waste, in addition to the dams dam, called environmental liabilities (PAM); In addition, do they consider supplies and raw materials less aggressive than the current ones, such as cyanide (gold separation), spaces for safekeeping, handling and use of hazardous material? Is the exploitation of the mineral resource projected for the use of future generations?

4. Does the Mining and Metallurgical Industry consider processes that involve explosives that allow the disturbance to the earth to be minimized and thus also achieve an effective conservation of terrestrial ecosystems (SDG 6 and 7)?

\section{Results}

The findings of the mining experts and environmental mining topics, subject in order of the questions expressed above, are described below and in an integrated manner. The analysis and interpretation of the information obtained, was in charge of the researchers, however their descriptions were reviewed by the experts, so as not to generate trends or misrepresent some data. The main challenges, which are described below, emanate from the interrelation that is made both in the questions, and in the literary foundation expressed in this document, and are:

\section{A. Input reduction (water):}

\section{Problematic:}

PAMs can cause contamination of surface and groundwater and represent a risk of changing the hydrological and / or hydrogeological regime. The pollution is due to the release of toxic substances contained in mining waste and, from mining works, open pit and underground mines. The major source of such contaminants are reagents used in the processing of minerals. With each passing year, water becomes a more critical problem for the mining sector, as the laws of minerals decrease, more water is needed to extract the same amount of ore, which increases the water needs in the industry. At the same time, the demand for water is increasing worldwide, driven by population growth, industrial development, the expansion of low-risk agriculture and the increase in per capita consumption (WWAP, 2019).

\section{Strategy expressed by the participants:}

Water scarcity is not the only problem facing mining companies, in some regions ice melting, storms, have the potential to generate excess water, increasing the risk of tributary leakage. Faced with these challenges, mining companies must improve their approach or sustainable strategy of water management, that is to use innovative ways to reduce, reuse and recycle water in regions with scarcity; Contain and treat wastewater to prevent spills or contamination of downstream water flows and monitor (digitally) their use and purity.

They add that by using water in various mining site activities, an action in favor is the diversion of surface water and pumping of the underground, in this way mining operations can reduce both the quantity and quality available for aquatic ecosystems and other industrial users and municipal. These pumping and channeling, would allow it to be also used to supply the diverse needs of mineral processing, dust suppression, etc., being able to avoid droughts of the tributaries and maintain the level in the wells. This would also lead to not affecting the slopes and streams, which feed the flora and fauna.

\section{B. Reduction of inputs (Energy)}

\section{Problematic:}

Mining and metal processing can be processes that consume excessively energy, which represents a significant source of air pollution, for example, the use of diesel fuel, used in trucks and excavators, electricity is used to power large equipment ore grinding and refining and smelting of various minerals, such as in Mexico, copper, aluminum, lead, silver, gold, zinc, among others.

\section{Strategy expressed by the participants:}

The mining industry is developing and using a series of strategies and technologies to reduce the environmental impacts derived from the entry of energy, these involve strong budgetary items, since changes must be made, that is, updating the mining equipment, from the extractive, to those of mineral processing, adopting even new houses or firms that already have sustainable equipment, with smaller dimensions and with greater operational capacity. 
Which by their design, in addition, contain the generated emissions, so these are minimal and in their process they are purified, reducing air and soil pollution.

\section{Ticket reduction (earth disturbance)}

\section{Problematic:}

Currently mined sites disturb a small fraction of the total land area of the earth. Achieving fractures in buildings or problems associated with the use of soil, since they can suffer both an impact from pollution, vibration and erosion and degradation, since it has its origin in the drag of the material contaminated by the wind and pollution due to inadequate disposal of waste and chemicals in mining operations.

Erosion and degradation of soils is due to the exposure of removed and processed materials, the destruction of the existing protective plant layer and also by the disposal of mining waste on the surface, considered PAM.

Another situation associated with the PAMs is the dragging of particulate material by the action of the wind that could contaminate the soil and affect people or animals by inhalation, ingestion or dermal contact (Parodi, 2010).

Strategy expressed by the participants:

Establish an adequate legal framework under a defined institutionality, as a fundamental element for the necessary policies to be applied to mitigate, remedy or avoid specific sites, expansions or concentration of previously untreated or previously separated MAP.

They express that at this point, the need for exchange and updating of mining equipment for more friendly and sustainable technology is reinforced, having to create important budget items to achieve this point. Erosion remediation would be minimized since the separation and refining of minerals would be more effective with more specialized equipment than the current ones, the handling, use and storage of reagents would be minimal and the waste would become a usable product in different industries ; with it, even the landscape would improve.

\section{Output reduction}

\section{Problematic:}

Mine wastes include solids, water and air particles, which can vary significantly in their composition and the potential for environmental pollution; In addition, the large volumes of waste produced in most mining sites cannot be hidden, they are well dammed, the so-called PAM.

Mining activities are carried out in a relatively small area, however related infrastructure and pollution of activities have the potential to affect the health of entire ecosystems, as well as reduce their ability to provide the necessary assets for human and environmental well-being. This includes the purification of water and air, the decomposition of waste materials that may be compromised when ecosystems are saturated by high levels of pollution.

\section{Strategy expressed by the participants:}

In addition to preventing contamination of soil, water and air, waste management plans are required to select and design suitable storage facilities to minimize the expansion of these (dam dams, PAMs).

The sector must adopt less aggressive processes, this includes the use of reagents and various supplies, which may derive from the adoption of foreign methods or give rise to investigations, which must also be sponsored and endorsed by the sector; companies must create links with research institutions and allow them to function as on-site laboratories.

\section{Conclusions}

The impact that emanates from miningmetallurgical activities, during its operation to ecosystems and terrestrial lives can remain after the abandonment of the mine temporarily or permanently.

Mining can have or express a high level of sustainability, according to the analysis of the results of the focus group, provided that the sector develops and integrates practices that reduce the environmental impact of its operations, with low measures, medium and high degree of complexity depending on the impact you want to avoid or minimize. 
In order to reduce the consumption of water and energy, minimize the disturbance of the land, the production of waste, prevent the contamination of soil, water and air and, in turn, the closure of mining units are effective as well as recovery activities, global efforts are required, where government, business, society, even individuals, actively participate without politicizing the efforts applied.

To be more environmentally sustainable, mining operations must be carried out in a way that minimizes their impact on the environment and leaves mined sites in an acceptable state for reuse for people or ecosystems.

In this document, we tried to concentrate the closest challenges facing the Mining and Metallurgical Industry, described by world organizations.

An important general observation described in this focal activity is that environmental damage is a result of centuries of exploitation without supervision and controls based on rigorous standards, so it can be referred to as a high cost, for not having considered good practices, even for not having allowed scientific research that exposed knowledge of both the benefits, and the destruction caused by the sector in the environment, as well as the opportunities for updating both new theories, processes, equipment and technologies and more environmentally friendly.

\section{References}

Arranz, J., Alberruche, E., (2008). Minería, medio ambiente y gestión del territorio. España: Gráficas Monterreina.

Belda, Ignacio, 2018. Economía circular. Un nuevo modelo de producción y consumo sostenible. Madrid :Tébar Flores.

Cámara Minera de México. (2019). Informe Anual. Cd. de México: CAMIMEX.

CMMAD. (1987). Informe de la Comisión Mundial sobre el Medio Ambiente y el Desarrollo. Nairobi: Asamblea General .

CNUMAD. (1992). Conferencia de las Naciones Unidas sobre el Medio Ambiente y Desarrollo., (pág. 2).
Gómez, T. (2012). RSE y desarrollo sustentable. En: Raufflet, E., Lozano, J., Barrera, E. y García, C. eds., Responsabilidad social empresarial, 1 st ed. Naucalpan de Juárez, México: Pearson

Hamui, A., Varela, M., (2013). La técnica de grupos focales. Universidad Nacional Autónoma de México.

Hernández, B. (2009). La función estratégica de la comunicación en el desarrollo sustentable. Xico, Veracruz un ejemplo de aplicación. Tesis Doctoral. Universidad Veracruzana. México. Recuperado de: http://www.eumed.net/tesisdoctorales/2010/tbh $\mathrm{h} /$ Antecedentes $\% 20 \mathrm{y} \% 20$ perspectivas $\% 20$ del $\%$ 20desarrollo\%20sustentable.htm

International Council on Mining \& Metals. (17 de mayo de 2019). Obtenido de https://www.icmm.com/website/publications/pd fs/commitments/181126_performanceexpectations.pdf

Martínez, R., Rivera, P., (2017). Articulación de los objetivos de Desarrollo Sostenible y la Legislación Ambiental en la Industria Minera. REMINEO: México.

Melo, R., (2011). Evaluación de un pasivo ambiental metalúrgico. UASLP: México.

Moran, Robert. (23 de julio de 2013). Observatorio de Conflictos Mineros de América Latina. Obtenido de https://www.ocmal.org/robert-moran/

Organizacion de Naciones Unidas. (2011). Guia para la elaboracion de Memorias de Sostenibilidad. México.

ONU-MÉXICO. (12 de septiembre de 2017). Metas de los Objetivos de Desarrollo Sostenible. Cd. de México.

Parodi, P. (2010). Gestión de los costos ambientales en la actividad minera. Foro virtual de contabilidad ambiental y social. Centro de Modelos Contables (CECONTA), (págs. 1-18). Buenos Aires. 
PNUMA. (2010). Informe anual . Nairobi: Sección de servicios de publicación de la ONU. Saade, Hazin Miryam. (2014). Buenas Practicas que favorezcan una mineria sustentable. La problemática en torno a los pasivos ambientales en Australia, el Canadá, Chile, Colombia, los Estados Unidos, México y el Perú. Santiago de chile : ONU-CEPAL.

SEMARNAT, (2007). La Carta de la Tierra. México, D.F.: Secretaría del Medio Ambiente y Recursos Naturales. Recuperado de: http://biblioteca.semarnat.gob.mx/janium/Docu mentos/Cecadesu/Libros/202455.pdf

Tretreault, Darcy. (Septiembre 2013). La Megamineria en México, Reformas estructurales y resistencia. Letras Verdes. Revista Lationamericana de Estudios Socioambientales No. 14, 214-.

WWAP. (2019). Informe Mundial de las Naciones Unidas sobre el desarrollo de Recursos Hidricos 2019. No dejar a nadie atras. París: UNESCO. 